\author{
Arkadiusz Kierys \\ (Historiographical Society, Branch in Toruń, Poland) \\ https://orcid.org/0000-0002-3607-527X \\ E-mail: akierys@liceum.umk.pl
}

\title{
Nie wszystko złe, co z epoki saskiej. Refleksje na temat ocen historiografii polskiej na przykładzie konfederacji tarnogrodzkiej
}

\begin{abstract}
Not Everything That's Bad Comes From the Saxon Era. Reflections on the Evaluation of Polish Historiography with the Example of the Tarnogród Confederation
\end{abstract}

\begin{abstract}
Critical evaluation of the reign of the Wettin dynasty in the Polish-Lithuanian Commonwealth dominated Polish historiography until the mid-20th century. August II the Strong was blamed for bringing the monarchy under the control of Peter I the Great, and the nobility for anarchizing political life - in a word, for the beginning of the collapse of the state. The study of the course of the Confederation of Tarnogród and the analysis of pacification talks between the Confederates and the King's plenipotentiaries, based on Diariusz Konfederowanych na Kongresie Lubelskie de Anno 1716 (Diary of the Confederates at the Congress of Lublin, 1716), allowed for a revision of the previous views. The nobility of the day were not only aware of the need to repair the system and describe the offices (mainly those of the Hetman), but also saw the need to curb the increasing role of

\begin{tabular}{|l|l|l|l|}
\hline \multicolumn{2}{|l|}{ PUBLICATION INFO } \\
\hline
\end{tabular}
\end{abstract}


Russia in the mediation. The most intriguing issue related to the Tarnogród Confederation seems to be the attitude of the nobility towards religious dissidents - they stood up for their rights, opposing the Catholic hierarchy as well as the king himself.

Key words: Confederation of Tarnogród, Polish-Saxon Union, August II the Strong, Stanisław Ledóchowski, Silent Sejm

\section{STRESZCZENIE}

Krytyczna ocena panowania dynastii Wettinów w Rzeczypospolitej Obojga Narodów dominowała w polskiej historiografii aż do połowy XX w. Augusta II Mocnego obarczano odpowiedzialnością za oddanie monarchii pod kontrolę Piotra I Wielkiego, a szlachtę za anarchizowanie życia politycznego - słowem początek upadku państwa. Badania przebiegu konfederacji tarnogrodzkiej oraz analiza rozmów pacyfikacyjnych między skonfederowanymi a plenipotentami króla - w oparciu o Diariusz skonfederowanych na Kongresie Lubelskim de Anno 1716 - pozwoliły na rewizję dotychczasowych poglądów. Szlachta ówczesna była nie tylko świadoma potrzeb naprawy ustroju i opisania urzędów (głównie hetmańskiego), ale także dostrzegała konieczność ukrócenia zwiększającej się roli mediacyjnej Rosji. Najbardziej intrygującą kwestią związaną z konfederacją tarnogrodzką wydaje się postawa szlachty wobec dysydentów religijnych - stanęli oni w obronie ich praw, sprzeciwiając się tym samym hierarchii katolickiej, jak i samego króla.

Słowa kluczowe: konfederacja tarnogrodzka, unia polsko-saska, August II Mocny, Stanisław Ledóchowski, Sejm niemy

Pamięci prof. Jacka Staszewskiego

W całej historii Polski nie ma boleśniejszej, okropniejszej, bardziej upokarzającej epoki jak czasy saskie. Polak przestał być panem w swoim własnym domu: gospodarowali cudzoziemcy i rządzili się jak głodne gęsi w stodole, wszelki opór zwalczając podstępem, groźbą lub orężem. I oto Polska, o której względy ubiegała się niegdyś cała Europa, stała się teraz jej pośmiewiskiem. Ignacy Chrzanowski

Poglądy na czasy saskie ukształtowane przez tuzów polskiej historiografii: Kazimierza Jarochowskiego, Józefa Feldmana, a przede wszystkim Władysława Konopczyńskiego odbiły niezatarte i niestety, wydawać by się mogło, "wiecznie” negatywne piętno na ocenie panowania królów saskich w Polsce ${ }^{1}$. Nawet dwie najbardziej znane i rywalizujące ze sobą szkoły historyczne w Polsce - krakowska i warszawska - mówiły niemalże jednym głosem na temat dynastii Wettynów, używały do tego

1 H. Olszewski, Epoka saska w ocenie historiografii polskiej, w: Między wielka polityka a szlacheckim partykularzem. Studia z dziejów nowożytnej Polski i Europy, red. K. Wajda, Torun 1993, s. 13-29; J. Staszewski, Czasy saskie - rehabilitacja czy lepsze poznanie?, „Wiadomości Historyczne" 1997, 221, 2, s. 65-75; idem, Badania Józefa Andrzeja Gierowskiego nad epoka saska, w: Profesor Józef Andrzej Gierowski jako uczony i nauczyciel, red. M. Markiewicz, Wrocław 2008, s. $46-50$. 
epitetów w stylu: ciemne, apatyczne, nieprodukcyjne, po prostu „próżniacze bezjutrze" 2 .

Raz przylepiona łatka trzymała się dobrze, negatywny sąd powtarzali publicyści, eseiści i historycy zawodowi: Paweł Jasienica zaczynał od Sasów Dzieje agonii Rzeczypospolitej, a Norman Davies przypomina opinię, jakoby powszechnie uważało się ten okres historyczny za najbardziej żałosny i upokarzający dla kraju - po prostu: „pięknie fosforyzująca kupa próchna"3. Także kulturoznawcy podzielali podobne zdanie: Aleksander Brückner porównywał ówczesne państwo do uprawy rolnej, „zachwaszczonej haniebnie” w "czasach nieszczęsnych"4; nieco delikatniej wypowiadała się Maria Bogucka, zachowując jednak sąd powszechny o najgłębszym wówczas upadku Rzeczypospolitej $j^{5}$. Czesław Miłosz w Historii literatury polskiej pisanej na emigracji dla odbiorcy anglojęzycznego

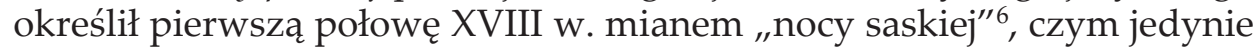
kontynuował myśl innego literaturoznawcy Ignacego Chrzanowskiego przytoczoną w motcie ${ }^{7}$.

Przy okazji autorzy, dla usprawiedliwienia swoich sądów, przypominali o niepowodzeniach w polityce międzynarodowej i wewnętrznej: klęska w wojnie północnej, dwukrólewie w latach 1704-1706, uzależnienie od Rosji, wzrost znaczenia możnowładztwa, klęska w wojnie siedmioletniej i ogólna anarchia zabierająca siły witalne monarchii. Koronnym argumentem na niekorzyść Augusta II miały być jego permanentne zabiegi „rozbiorowe” Rzeczypospolitej, jakich jakoby dopuszczał się przy okazji kontaktu z przedstawicielami dyplomacji krajów ościennych - oczywiście najczęściej Prus ${ }^{8}$. W kwestiach społecznych już tak źle nie było, ale na bilans panowania Wettynów i tak miał wpływ - głośny za granicą - tumult toruński i jego fatalne konsekwencje, ewidentnie niekorzystne dla oblicza Polski i Polaków w świecie. Podsumowując więc, unia polsko-saska była dobrym nawozem do wzrastania kraju, który stanie się

2 Por. ocenę czasów saskich w: J. Szujski, Dzieje Polski, t. 4, Kraków 1866; M. Bobrzyński, Dzieje Polski w zarysie, Warszawa 1974; T. Korzon, Odrodzenie w upadku. Wybór pism historycznych, Warszawa 1975; S. Askenazy, Wczasy historyczne, t. 1-2, Warszawa-Kraków 1902-1904.

3 N. Davies, Boże igrzysko. Historia Polski, Kraków 2006, s. 457.

4 A. Brückner, Dzieje kultury polskiej. Czasy nowsze do roku 1831, t. 3, Kraków 1931, s. 6-7.

5 M. Bogucka, Dzieje kultury polskiej do 1918 roku, Wrocław 1991, s. 218-219.

6 C. Miłosz, Historia literatury polskiej, Kraków 2010, s. 188.

7 I. Chrzanowski, Reforma szkolna Konarskiego, w: idem, Optymizm i pesymizm polski. Studia z historii kultury, Warszawa 1971, s. 67.

8 J. Staszewski, Czasy saskie, s. 70. 
słabym i bezbronnym „człowiekiem Europy” na tyle, że bez trudu będzie się można nim podzielić.

Ostatnimi czasy ukazały się dwie poważne syntezy dziejów polski okresu nowożytnego: Mariusza Markiewicza ${ }^{9}$ i Urszuli Augustyniak ${ }^{10}$. Obie niezaprzeczalnie odstają in plus od dawniejszej historiografii ${ }^{11}$, oparte na najnowszych badaniach dają pełniejsze i przez to bliższe prawdy historycznej dzieje panowania dynastii niemieckiej w Rzeczypospolitej. Główne punkty ciężkości kładą autorzy na sytuację międzynarodową i wynikającą z niej sytuację Polski i Litwy. Markiewicz zwraca uwagę na ogólną zmianę geopolityki europejskiej początków XVIII w. - odmiennej od wieku XVII - zaniku dotychczasowych głównych graczy politycznych Europy Środkowo-Wschodniej: potęg Szwecji i Turcji, i pojawieniu się nowych: Rosji i Prus. „Skończyły się konflikty charakterystyczne dla XVII w. - pisze. - Zanikło zagrożenie szwedzkie i tureckie, Rzeczpospolita przestała aktywnie uczestniczyć w kształtowaniu sytuacji politycznej w tej części Europy. Do czasu Stanisława Augusta Poniatowskiego będzie zachowywać mniej lub bardziej respektowaną przez inne państwa neutralność" 12 . Państwo dwóch narodów nie odgrywało już roli podmiotu stosunków międzynarodowych, stawało się powoli, ale konsekwentnie przedmiotem tejże gry $w$ rękach wzrastających potęg. W tym samym duchu wypowiada się Augustyniak:

Dla dziejów Rzeczypospolitej Obojga Narodów największe znaczenie miały zmiany zachodzące od pocz. XVIII w. w regionie Europy ŚrodkowoWschodniej. W próżnię polityczną powstałą po osłabieniu w wyniku wielkiej wojny północnej Turcji i Szwecji - tradycyjnych sojuszników Francji, wkroczyły Rosja i Brandenburgia - dysponujące lepszym aparatem administracyjnym i wojskowym. W 2. poł. XVII w. dobijały się one statusu mocarstw, który osiągnęły do poł. XVIII w., rozbudowując swe armie do poziomu porównywalnego z dotychczasowym supermocarstwem, Francją. Ich awans radykalnie zmienił oblicze polityczne Europy w XVIII w. ${ }^{13}$

Powracając jednak do spraw "domowego porządku”, czyli kwestii wewnętrznych, żmudne badania uczonych powojennego pokolenia

\footnotetext{
M. Markiewicz, Historia Polski 1492-1795, Kraków 2007.

10 U. Augustyniak, Historia Polski 1572-1795, Warszawa 2008.

11 Pierwszą syntezą historii Polski, która w odmienny od zastanego do tej pory stanu podjęła dyskusję nad kondycją państwa Obojga Narodów pod panowaniem dynastii saskiej, była praca zbiorowa: Polska na przestrzeni wieków, red. J. Tazbir, Warszawa 1995.

12 M. Markiewicz, op. cit., s. 613.

13 U. Augustyniak, op. cit., s. 748-749.
} 
(głównie Józefa A. Gierowskiego i Jacka Staszewskiego) ${ }^{14}$ zrewidowały poglądy ich przedwojennych mentorów na czasy saskie jako rzekomego początku upadku Rzeczypospolitej. Obecnie zwraca się uwagę na więcej niż konstruktywne programy reform państwa polsko-litewskiego opracowane przez Augusta II Mocnego, który jeszcze przed objęciem tronu wydał słynną, niestety niedokończoną broszurę: Jak Polskę przeksztatcić w kraj kwitnacy $i$ cieszacy się szacunkiem u sąsiadów ${ }^{15}$. Program przewidywał stałą płacę dla armii, istnienie sprawnej służby dyplomatycznej, powołanie czterech uniwersytetów (dla poprawy wiedzy legislacyjnej społeczeństwa) i przede wszystkim rozwój handlu - w kraju będącym według niego naturalnym pośrednikiem między Wschodem i Zachodem.

Nie potwierdzają się również tezy, jakoby Sas zamierzał wprowadzić rządy absolutystyczne, podobne do tych z własnego elektoratu Saksonii - a te z kolei wzorowane miały być na Francji Ludwika XIV. Pomijając fakt, że w elektoracie August nie posiadał absolutum dominium, o czym świadczy chociażby mocna pozycja Landtagu (przedstawicielstwa stanów) skutecznie kontrolującego finanse dworu ${ }^{16}$, to i w państwie Obojga Narodów taki pomysł się nie narodził - przynajmniej na początku panowania - a i ten pogląd jest wielce kontrowersyjny. Przyjęcie imienia tronowego: „Augusta II" było gestem w stronę poddanych polskich, nawiązaniem do ostatniego z rodu Jagiellonów, Zygmunta Augusta, a także wyrażeniem woli przywrócenia w Polsce najlepszych lat świetności-choć nie tylko - był to także swego rodzaju program polityczny:

[...] król uwierzył, iż przywrócenie utraconej przez jego poprzedników władzy królewskiej będzie możliwe, gdy on sam stanie się władcą dziedzicznym fragmentu terytorium Rzeczypospolitej. Wówczas nastąpi kontynuacja - jak u Jagiellonów - elekcji kolejnych synów królewskich, tzn. Wettynów, co zapewni ciągłość godności królewskiej w jego domu. Zatem od początku zakusy na Mołdawię i Wołoszczyznę, na Prusy Książęce, na Inflanty i wreszcie na Litwę, występujące w pierwszych latach rządów, miały źródło w połączeniu "praktycznego" niejako celu - wzmocnienia władzy królewskiej - z celem dynastycznym: utrwaleniu godności królewskiej w domu Wettynów ${ }^{17}$.

14 Za przykład posłużyć mogą klasyczne już prace: J.A. Gierowski, Między saskim absolutyzmem a złotą wolnością. Z dziejów wewnętrznych Rzeczypospolitej w latach 1712-1715, Wrocław 1955; idem, Traktat przyjaźni Polski z Francja w 1714 r. Studium z dziejów dyplomacji, Warszawa 1965; idem, W cieniu Ligi Pótnocnej, Wrocław 1971; J. Staszewski, O miejsce w Europie. Stosunki Polski i Saksonii z Francja na przełomie XVII i XVIII w., Warszawa 1973; Rzeczpospolita w dobie upadku, 1700-1740. Wybór źródet, oprac. i wstęp J. Gierowski, Wrocław 1955.

J. Staszewski, August II Mocny, Wrocław 1998, s. 53.

16 Ibidem, s. 38-44.

17 Ibidem, s. 71. 
Metody takie - analiza tego, co możliwe i niemożliwe, i wybór najlepszej, a przez to najmniej radykalnej drogi realizacji własnych pomysłów reformatorskich - staną się znakiem firmowym Augusta II. Oczywiście, to co dla niego było próbą wzmocnienia państwa przez wzmocnienie dynastii, uchodziło w oczach szlachty nie za realizację pactów conventów (odzyskania awulsów), lecz dążeniem do zniesienia wolnej elekcji i wprowadzenia elekcji vivente rege. Działalność międzynarodowa - dyplomacja i wojna - miała zrealizować cele dynastyczne i krajowe (zarówno w stosunku do Saksonii, jak i Rzeczypospolitej - a więc wzmocnić pozycję władcy, nie naruszając przywilejów stanowych). Jednakże właśnie ta nadaktywna polityka zewnętrzna doprowadziła $\mathrm{w}$ ostateczności do krachu wszelkich pomysłów reformatorskich i - wbrew woli Polski - zaangażowania jej w kolejną wielką wojnę, zakończoną kolejnymi stratami ludzkimi i materialnymi, zagrożeniem suwerenności państwa, a w konsekwencji zachwianiem zaufania szlachty do króla. A mimo to promonarchiczna konfederacja sandomierska stanowiła niezaprzeczalną większość szlachty koronnej - wiernie oddającej swoje szable prawowitemu władcy.

Wielka wojna północna zmieniła także relacje w stosunkach August II - Piotr I Wielki. O ile jeszcze w 1699 r., a więc w przeddzień ataku na posiadłości szwedzkie w Inflantach, byli sojusznikami na równych prawach, to dalsze klęski Wettyna, a szczególnie jego abdykacja na rzecz Stanisława Leszczyńskiego i w konsekwencji odzyskanie tronu dzięki zwycięstwu rosyjskiemu nad Szwedami pod Połtawa, sprawiły, że August II stał się dłużnikiem cara Rosji. Spotkanie w Toruniu (1709) potwierdziło tylko tę zależność i wraz ze zmianą polityki międzynarodowej Piotra - z czarnomorskiej na bałtycką - zmieniło także całkowicie pozycję Rzeczypospolitej w oczach Petersburga. Polsko-litewska monarchia była od teraz korytarzem do Europy Zachodniej, podporządkowanie jej było naturalną konsekwencją okcydentalnych koncepcji cara. August II nie pogodził się z takim stanem rzeczy i natychmiast rozpoczął aktywną działalność dyplomatyczną zmierzającą do neutralizacji dominującej pozycji Rosji - stąd też traktaty z Paryżem (1714) i Wiedniem $(1719)^{18}$. Nie mogły one jednak skutecznie zapobiec rodzącemu się właśnie - bardzo niebezpiecznemu dla Polski - sojuszowi północnoeuropejskiemu: Rosji i Prus. Kraje te wiązały ",aspiracje polityczne Piotra i apetyty terytorialne Prus"19, a wszystko podlane innowierczą propagandą umożliwiającą

18 J. Staszewski, Między Wiedniem i Petersburgiem. Uwagi na temat międzynarodowego potożenia Rzeczypospolitej w XVII i XVIII w., w: Między Wschodem i Zachodem - Rzeczpospolita XVI-XVIII w. Studia ofiarowane Zbigniewowi Wójcikowi w siedemdziesiąta rocznice urodzin, red.

T. Chynczewska-Hennel et al., Warszawa 1993, s. 173-174.

19 Idem, August II na polskim tronie, w: Polska, s. 313. 
ingerencję w wewnętrzne sprawy Rzplitej, np. poprzez wykorzystanie kwestii dysydenckiej.

W roku 1713 wojska saskie przerzucono z Pomeranii Szwedzkiej do Rzeczypospolitej, gdzie miały z Duńczykami bronić ściany pomorskiej przed Szwedami, oficjalnie, by wzmocnić siły Korony i zabezpieczyć granice od strony Turcji, która dwa lata wcześniej, jako sojusznik Karola XII, odniosła zwycięstwo nad Piotrem I w bitwie nad Prutem, wywołując niebezpieczną sytuację odrodzenia sił koalicji szwedzko-tureckiej ${ }^{20}$. W rzeczywistości Sasi stanowili zabezpieczenie dla reform Augusta II i niebagatelny argument, by je w wypadku realizacji wymusić w przekonywający sposób. A chodziło o zniesienie lub ograniczenie liberum veto i wolnej elekcji, a także reformy skarbu, wojska i samego sejmu ${ }^{21}$. Król miał nadzieję, że antagonizmy szlachecko-możnowładcze są większe niż antagonizmy polsko-saskie. Tymczasem zła kondycja gospodarcza wywołana latami nieurodzaju i przemieszczającymi się w czasie wojny północnej wojskami - niestroniącymi od rabunku - doprowadziła do sytuacji, w której ciężary utrzymania cudzoziemskich autoramentów i sposób ich egzekwowania (kontrybucjami) natychmiast wywołał wybuch konfederacji generalnej.

Zawiązana została w Tarnogrodzie pod koniec listopada 1715 r., pod laską marszałka Stanisława Ledóchowskiego - „człowieka o tak wybitnych walorach moralnych, iż po raz ostatni może mieliśmy do czynienia $\mathrm{z}$ ruchem szlacheckim, broniącym wartości sarmackiego państwa $\mathrm{w}$ ich najbardziej pozytywnych treściach" - pisze Staszewski ${ }^{22}$. Jasnym też było wszystkim, że S. Ledóchowski, jako marszałek związku wołyńskiego, przyprowadził najwięcej chorągwi i miał dodatkowo poparcie nie byle kogo, bo samego wojewody krakowskiego - Janusza Wiśniowieckiego ${ }^{23}$. Konfederaci wysunęli postulaty naprawy exorbitancji - a więc niczego ponad przywrócenia złamanych praw Rzeczypospolitej. Chodziło przede wszystkim o wyprowadzenie wojsk saskich z granic państwa polskiego, a tym samym zaprzestania utrzymywania ich, odsunięcia ministrów saskich od spraw domowych i gwarancji zachowania status quo w ustroju

\footnotetext{
20 Historia dyplomacji polskiej, t. 2, red. Z. Wójcik, Warszawa 1982, s. 366-367.

21 Por. J. Feldman, Geneza konfederacji tarnogrodzkiej, „Kwartalnik Historyczny” 1928, 42, 3, s. 496; J. Staszewski, August II Mocny, s. 195-196; M. Markiewicz, Historia, s. 610-611.

22 J. Staszewski, August II na polskim, s. 313.

23 W. Kriegseisen, Samorzad szlachecki w Małopolsce w latach 1669-1717, Warszawa 1989, s. 164 .
} 
demokracji szlacheckiej. Szlachta odwoływała się do boskiego i naturalnego prawa pozwalającego jej stanąć nawet przeciw własnemu suwerenowi; uzależniała zarazem powrót na łono królewskie od przywrócenia przez niego połamanych praw ${ }^{24}$. Początkowe działania polegały na wzajemnym unikaniu starcia w polu - głównie ze strony skonfederowanych - i prowadzeniu równolegle negocjacji, pierwsze z nich, w Rawie Ruskiej, zakończyły się jednak niepowodzeniem.

Po wybuchu rokoszu tarnogrodzkiego, zarówno konfederaci, jak i wojska koronne - ewidentnie wrogie wojskom saskim - liczyły na akces hetmanów do związku szlacheckiego; tymczasem Adam Sieniawski, hetman wielki koronny, "pokazał się jako opieszały polityk” i wyczekujący gracz polityczny - zyskując przez to raczej pogardę niż autorytet wśród braci szlacheckiej ${ }^{25}$. Żądano od niego złożenia funkcji na rzecz marszałka konfederacji, jasnym bowiem było, iż sam związek szlachecki nie da rady wojskom saskim, bez wsparcia koroniarzy. Wzajemne antagonizmy, a szczególnie całkowicie „niejasna” postawa hetmana, który grał wyraźnie na obie strony, doprowadziła do konfrontacji. Związkowcy zajęli Lwów - w którym przebywał - i bez ceregieli aresztowali hetmana. Przewożono go w różne miejsca, aż w końcu umieszczono w Łącznej, kwaterze tarnogrodzian, i tam przygotowywano proces, oskarżając go między innymi o umożliwienie wojskom saskim wejścia $\mathrm{w}$ granice Rzeczypospolitej. Ostatecznie Sieniawski nie stanął przed trybunałem, inne też wypadki zdecydowały o losie konfederacji - na Wołyń wkroczyły wojska rosyjskie ${ }^{26}$.

Mediacja rosyjska i niedwuznaczna ingerencja wojsk rosyjskich na południu kraju była wynikiem zbyt śmiałych kalkulacji tarnogrodzian; po odrzuceniu traktatu rawskiego ostentacyjnie zaprosili do mediacji księcia Grigorija Fiodorowicza Dołgorukiego - czemu z kolei August II chciał za wszelką cenę zapobiec, zdając sobie sprawę, jak bardzo jest to niebezpieczna gra i jak wiele może on Rzeczpospolitą kosztować ${ }^{27}$. Próby porozumienia z konfederatami, poza plecami cara, nie były już możliwe wobec nieustępliwej postawy S. Ledóchowskiego. Szlachta sięgnęła jeszcze po poparcie włościan - po raz pierwszy w dziejach konfederackich

24 Na temat zawiązania, struktury, funkcjonowania i celów konfederacji zob.: W. Stanek, Generalny zjazd tarnogrodzki w 1715 r., w: Między wielka, s. 264-266; idem, Konfederacje generalne koronne w XVIII wieku, Torun 1991, s. 53.

25 Hetmani Rzeczypospolitej Obojga Narodów, red. M. Nagielski, Warszawa 1995, s. 286.

26 E. Otwinowski, Dzieje Polski pod panowaniem Augusta II, wyd. A. Mułkowski, Kraków 1849, s. 265; J. Wimmer, Wojsko Rzeczypospolitej w dobie wojny pótnocnej (1700-1717), Warszawa 1956, s. 420-421.

27 A. Prochaska, Konfederacja tarnogrodzka, „Przewodnik Naukowy i Literacki” 1917, 45, $1-11$, s. 365-447. 
- wydano manifest do chłopów, by ich oddziały nie tylko gromiły okrutnych i znienawidzonych Sasów, ale czyniły to „i w oczy, i z tyłu, i wszelką zdradą" 28 - by świętą wiarę katolicką ocalić i wdzięczność stanu szlacheckiego zyskać, a przede wszystkim, by zapracowany szmat chleba w pokoju jeść mogli.

Inicjatywa jeszcze należała do rokoszan, kiedy inicjowała wystąpienia w Wielkopolsce i na Litwie (gdzie postawa hetmana Ludwika Pocieja przypominała tę z Korony). Jeszcze na początku rozmów w Lublinie - pod opieką mediatora G.F. Dołgorukiego - wydawało się, że to szlachta jest stroną rozgrywająca; lecz czas wyraźnie działał na jej niekorzyść. Osobiste spotkanie Augusta II i Piotra I w Gdańsku zdecydowało, w którą stronę ruszą regimenty Jego Wieliczeństwa. Nie pomogła nadzieja konfederatów, że mogą jeszcze odegrać jakąś rolę w mediacji między Piotrem I a Karolem XII, czego rzeczywiście car początkowo oczekiwał - co miało zakończyć przedłużającą się wojnę północną i ostatecznie utwierdzić pozycję Rosji nad Bałtykiem; nie przyniosły skutku własne misje dyplomatyczne do Wiednia i Wysokiej Porty, a podwójna gra konfederatów, którzy zachęcali Turcję do konfrontacji z Rosją przekreśliła ostatecznie możliwość współpracy z G.F. Dołgorukim ${ }^{29}$. Piotr I Wielki ponownie stał się protektorem polskiego króla, konfederatów uznając tym samym za „ad versa Partis Rebelizantów" - działających przeciw ojczyźnie rebeliantów ${ }^{30}$.

Przeniesienie działań konfederackich na Wielkopolskę i Prusy Królewskie powiodło się tylko połowicznie, co prawda regimentarz związkowy Chryzostom Gniazdowski zajął Poznań, a później Toruń, lecz niedługo potem doznał upokarzającej klęski od wojsk saskich pod Kowalewem $^{31}$. Od tej pory pozostały już tylko rokowania, zmusiła do nich sytuacja patowa, jaka wytworzyła się po pierwszych potyczkach: ani August II nie dysponował wystarczającymi siłami, by dobić przeciwnika, ani tym bardziej rokoszanie nie mieli szans na pokonanie regularnych

28 Cyt. za: A. Link-Lenczowski, Rzeczpospolita na rozdrożu 1696-1736, Kraków 1994, s. 53.

29 J.A. Gierowski, Konfederaci tarnogrodzcy wobec możliwości porozumienia szwedzko-rosyjskiego, w: Słowianie w dziejach Europy. Studia historyczne ku uczczeniu 75. rocznicy urodzin i 50-lecia pracy naukowej Profesora Henryka Łowmiańskiego, red. J. Ochmański, Poznań 1974, s. 253-254; J.A. Gierowski, J. Leszczyński, Dyplomacja polska w dobie unii personalnej polsko-saskiej, w: Polska stużba dyplomatyczna XVI-XVIII wieku, red. Z. Wójcik, Warszawa 1966, s. 393.

30 Archiwum Państwowe w Toruniu, Akta Miasta Torunia, katalog II, rkps sygn. VI-24, k. 176, Diariusz skonfederowanych na Kongresie Lubelskim de Anno 1716 [dalej: Diariusz].

31 K. Jarochowski, Wzięcie Poznania przez konfederatów tarnogrodzkich w dniu 24 lipca 1716 r., w: idem, Opowiadania Historyczne, Poznań 1860, s. 115-131; J. Wimmer, op. cit., s. 427. 
wojsk elektorskich. Rozmowy toczyły się długo i z mozołem, kilkakrotnie przerywane i przenoszone - z Lublina do Kazimierza, a w końcu do Warszawy - trwały łącznie prawie pół roku. Prym wiedli plenipotenci królewscy, a wśród nich biskup kujawski Konstanty Felicjan Szaniawski, druga osoba w hierarchii kościelnej po prymasie - stronę konfederacką reprezentował Józef Potocki, lecz on wyraźnie ograniczony był wolą marszałka Ledóchowskiego, kontrolującego swoich plenipotentów w sposób wręcz obsesyjny ${ }^{32}$.

Konfederacja tarnogrodzka ujawniła też z całą mocą rywalizację między szlachtą a magnaterią; niezadowolenie związkowców budziła zarówno postawa ministrów: Jana Przebendowskiego, podskarbiego wielkiego koronnego i Jana Szembeka, kanclerza wielkiego koronnego (zarazem wiernego stronnika cara Piotra), ale przede wszystkim dwulicowe zachowanie hetmanów, którzy lawirując między konfederatami a dworem, próbowali ugrać coś dla siebie i wzmocnić własną pozycję. Generalność związkowa wystąpiła z zażądaniem, jeśli nie zawieszenia, to przynajmniej „opisania" urzędu hetmańskiego, czyli po prostu ograniczenia jego prerogatyw, a najlepiej wymiany sprawujących dotychczas te funkcje - Adama Sieniawskiego i Ludwika Pocieja, hetmana wielkiego litewskiego ${ }^{33}$. Jako że ten ostatni był filarem polityki rosyjskiej w Rzeczypospolitej, głos zabrał w tej sprawie książę G.F. Dołgoruki, pełniący oficjalnie rolę mediatora $\mathrm{z}$ ramienia Piotra I; informował on obie zwaśnione strony, „że ma zlecenie od monarchy swego, aby ci hetmani, których wierność doznał w spólnych interesach, nie byli od urzędów oddaleni, że car [...] póki się wojna szwedzka nie skończy, innych na to miejsce nie dopuści"34. Deklaracja kniazia, reprezentującego człowieka, dzięki któremu August II zasiadał na tronie, a Korona i Litwa wolne były od szwedzkiego protektoratu, a przede wszystkim dysponował realną siłą zbrojną zdolną pokonać każdą ze stron, skutecznie zakończyła sprawę zmian personalnych.

Wiele uwagi i czasu poświęcali plenipotenci obu stron kwestii, którą ogólnie nazywali sprawami causae religionis. Dotyczyło to zarówno szkód poniesionych przez Kościół w parafiach i klasztorach podczas działań zbrojnych lub rekwizycji, jak i ograniczeń dla dysydentów w politycznym i społecznym tego słowa znaczeniu. Jako pierwsi poruszyli tę kwestię konfederaci w tzw. Kondycjach do traktatu, czyli propozycjach gradusów

32 Zob. Dziennik konfederacji tarnogrodzkiej przeciw wojskom saskim, zawiąanej w Polsce 1715-1717, wyd. E. Raczyński, Poznań 1841, passim [dalej: Dziennik].

33 J.A. Gierowski, "Opisanie” urzędów centralnych przez konfederatów tarnogrodzkich, w: O naprawę Rzeczypospolitej XVII-XVIII w. Prace ofiarowane Władysławowi Czaplińskiemu w 60. rocznice urodzin, red. J. Gierowski et al., Warszawa 1965, s. 195-198.

34 Dziennik, s. 198. 
przyszłego porozumienia ${ }^{35}$. Pierwszy punkt kondycji dotyczył dania satysfakcji za szkody, jakie dokonały wojska saskie w miejscach świętych; szczególnie zaznaczono, aby „starosta bogusławski Lubomirski - który Częstochowę najechał - żadnej nie miał od JKMści protekcji i przed sąd został postawiony"; zaraz też dodano, by zbory i inne po miastach, wsiach i dworach dla "dewocji dysydentów, bez pozwolenia erygowane za panowania JKMści zostały zniszczone, wyjąwszy te, które zgodnie z prawem zostały postawione" ${ }^{\prime 36}$. Żądania te nie były niczym innym, jak tylko powtórzeniem ogólnych haseł głoszonych od początku konfederacji, a mających na celu - poprzez wyrażenie chęci obrony wiary katolickiej - usprawiedliwienie wystąpienia szlachty przeciw majestatowi króla ${ }^{37}$.

Reprezentanci dworu przesuwali punkt ciężkości z wojsk saskich na żołdactwo szwedzkie. To w nich widziano sprawców najazdów i rabunków dóbr kościelnych i to oni mieli pod swoją opieką dysydentów, którzy wbrew prawom i konstytucjom „nowe zbory heretyckie erygowali” - plenipotenci króla zaznaczyli, że takie nadużycia mają być usunięte, a zbory demolowane ${ }^{38}$. Taką też postawę zajął August II w osobnym oświadczeniu skierowanym bezpośrednio do Ledóchowskiego ${ }^{39}$, ale publicznie sprawy religijne poruszone zostały dopiero przy kolejnym kryzysie traktatowym, kiedy to po zerwaniu obrad w Lublinie marszałek generalny konfederatów wydał uniwersał odwołujący się do wiary katolickiej i uczuć patriotycznych szlachty ${ }^{40}$. W podobnym tonie wyrażali się konfederaci niemal zawsze, gdy trzeba było stanowczo odpowiadać plenipotentom królewskim - głosili wówczas, iż konfederacja zawiązała się dla obrony „zgwałconych świątyń bożych"41. Widać z tego wyraźnie, że rokoszanie wykorzystywali kwestie religijne do własnych celów propagandowych bardziej niż rzeczywistej obrony interesów Kościoła. Strona królewska podchodziła do tych spraw z rezerwa nie negując żądań strony związkowej, ale ograniczając się jedynie do potwierdzania słuszności zarzutów i gotowości zadośćuczynienia za spowodowane szkody ${ }^{42}$.

Prawdziwa dyskusja miała miejsce dopiero na sesji warszawskiej w październiku 1716 r. Biskup kujawski Felicjan Szaniawski, jakby zapominając, czyim jest plenipotentem - a reprezentował majestat króla - żądał zrównania zbrodni przeciw „honorowi boskiemu” ze sprawami rangi

\footnotetext{
Kondycje do traktatu z 14 lipca 1716, w: Diariusz, k. 52.

Ibidem.

Manifest skonfederowanych z 13 czerwca 1716, w: Diariusz, k. 22.

Kondycje do traktatu ex parte JKMści z 23 lipca 1716, w: Diariusz, k. 28.

Respons ex parte JKMści z 23 lipca 1716, w: Diariusz, k. 31.

Kopia uniwersału marszałka generalnego z 27 sierpnia 1716, w: Diariusz, k. 37-38.

Diariusz, k. 24-25.

Respons od JKMści z 24 sierpnia 1716, w: Diariusz, k. 24.
} 
kryminalnej. Tak jednoznaczna i przesadzona deklaracja reprezentanta Kościoła katolickiego wzbudziła niezadowolenie zarówno konfederatów, jak i komisarzy królewskich. W imieniu tych ostatnich wystąpił sam feldmarszałek Jakub Flemming, najbliższy powiernik Wettyna i człowiek dobrze ustosunkowany wśród braci rycerskiego stanu ${ }^{43}$ - usprawiedliwiał ekscesy żołnierskie naturalnym prawem wojny. W kwestii praw dysydentów biskup kujawski proponował powtórzenie konstytucji z roku 1632 pozwalającej zachować postawione dotychczas zbory z równoczesnym zakazem stawiania nowych ${ }^{44}$. I tę propozycję ostatecznie zachowano i włączono do traktatu; w projekcie causae religionis traktatu warszawskiego (artykuł czwarty) zaznaczono na wstępie, że wiara rzymska katolicka jest w Królestwie Polskim prawowierna, a w prowincjach do niej należących - najprzedniejsza.

Co do praw dysydentów postanowiono powtórzyć konstytucje konfederacji generalnych warszawskich z lat 1632, 1648, 1668 i 1674, które oprócz dawnych zborów - ,z wolnym w nich nabożeństwa odprawianiem" - nowych stawiać nie wolno; innym zaś jedynie prywatnie po domach nabożeństwa odprawiać, jednakże bez kazań i śpiewu. Poza tym publicznych zgromadzeń, gdzie nawoływanoby do obcej wiary, odbywać nie wolno, a ci, którzy by ważyli się innych na swe obrządki zaciągać, najpierw karą pieniężna, a później więzieniem i wygnaniem karani będą. Sądy nad nimi wykonywać mają panowie marszałkowie Obojga Narodów lub sądy trybunalskie. Prawom tym nie podlegają panowie ministrowie, „którzy nabożeństwa swe [...] prywatnie odprawiać moga, tak jednak, iż inszym przychodzić do tego ich nabożeństwa [...] nie jest pozwolone" ${ }^{\prime \prime 4}$.

Nie mniej ważnym problemem, jaki stanął przed komisarzami obu stron, było wypracowanie nowego kształtu „unii” polsko-saskiej. Mimo że konfederaci postulowali ograniczenie roli ministrów saskich w kancelarii, administracji królewszczyzn i wojsku, to strona królewska wolała odłożyć rozmowy na ten temat do zakończenia wojny północnej. Plenipotenci Ledóchowskiego dążyli do szybkiego opisania urzędów centralnych, a także wymuszenia obietnicy niewprowadzania wojsk obcego autoramentu w granice Rzeczypospolitej ${ }^{46}$. Litwini dodawali jeszcze, by oficerowie ",bene nati et possessionati ze szlachty polskiej pochodzili" ${ }^{27}$. Konfederaci poruszyli kwestię garnizonu królewskiego, składającego się

43 Jakub Henryk Flemming nie tylko posiadł indygenat polski, ale też poprzez dwa małżeństwa powiązany był z rodami Sapiehów i Radziwiłłów.

44 H. Olszewski, Doktryny prawno-ustrojowe czasów saskich (1697-1740), Warszawa 1961, s. $163-164$.

45 Volumina Legum [dalej: VL], t. 6, wyd. J. Ohryzko, Petersburg 1860, s. 124-125.

46 Diariusz, k. 30v.

47 Dziennik, s. 220. 
z Sasów i Polaków - wcześniej bowiem odrzucono propozycję, by złożony był tylko z polskiego autoramentu. Przedstawiciele wojska domagali się też, aby oficerowie $\mathrm{w}$ polskich oddziałach nie byli peregrini, czyli obcego pochodzenia ${ }^{48}$. Na temat gwardii królewskiej postanowiono w końcu, iż złożona będzie z samych Sasów, nie uwzględniając zupełnie żądań rokoszan, którzy mimo to dopuszczali taką sytuację tylko do końca wojny ze Szwedami. Gwardię złożoną z 1200 ludzi powierzono komendantowi generalnemu $\mathrm{z}$ dwoma wicekomendantami; ponadto koszt utrzymania gwardii spadał na skarb elektorski ${ }^{49}$. Komendanci gwardii składać mieli przysięgę na wierność królowi i Rzeczypospolitej i podporządkować się jurysdykcji marszałkowskiej. Przed sądami marszałkowskimi mieli dochodzić sprawiedliwości ludzie pokrzywdzeni przez gwardzistów.

Opisano także urzędy ministerialne, i tak przy boku króla nie mogło być więcej jak sześć osób pochodzenia saskiego, a i one ograniczone były wyłącznie do zajmowania się sprawami urzędu elektorskiego, nie mieszając się do spraw "domowego porządku” ${ }^{50}$. Królowi nie można było przebywać poza granicami Rzeczypospolitej dłużej niż trzy miesiące w roku. Argumentując tę propozycję, konfederaci postulowali, iżby każda prowincja, a więc: Małopolska, Wielkopolska, Litwa i Saksonia miały po równo (miesięcy). Spotkało się to ze zdecydowanym sprzeciwem rzecznika interesów królewskich biskupa kujawskiego, ale w końcowym akcie nie zmieniono punktu konfederackiego ${ }^{51}$. Dodano natomiast punkt, w którym zapisano, że król może zamienić trzymiesięczny pobyt w Saksonii na sześciomiesięczny, jednakże raz na dwa lata i po przebytym sejmie (lub z powodów zdrowotnych). Rezydując w Saksonii August II nie mógł rozdawać wakansów; gdyby tego nie przestrzegał, powinien być niezwłocznie informowany o tym prymas. Kanclerze mieli ponadto pilnować, by król przestrzegał Pacta conventa, nie wszczynał wojny ofensywnej bez wiadomości i rady całej Rzeczypospolitej, a także by nienaruszone zostały prawa Polski do „Xsięstwa Kurlandzkiego y Semigalskiego, Powiatu Lawenburskiego, y Bytowskiego, tudzież kościołów Katolickich w tych i innych tegoż Państwa stronach Pruskich" 52 . Do obowiązków kanclerzy należało również kontrolowanie indygenatów, a szczególnie, „by przywilejów nie rozdawano dysydentom z krzywdą katolików”53.

\footnotetext{
Diariusz, k. 169-170.

Ibidem, k. 177-178v.

VL, t. 6, s. 117.

Diariusz, k. 178.

VL, t. 6, s. 118 .

Ibidem, s. 119.
} 
Traktat warszawski z listopada 1716 r. kończył de iure konfederację tarnogrodzka, ale nie kończył jej de facto; rokowania kontynuowano dalej, by uzgodnione gradusy uformować w konstytucje sejmowe. Powróciła sprawa „opisania" urzędów hetmańskich: postanowiono, iż osobom trzymającym buławę pozostawiono władzę nad wojskiem wraz z sądownictwem wojskowym. Odebrano natomiast uprawnienia skarbowe, zabroniono także wydawania wszelkich asygnacji i jakichkolwiek dyspozycji związanych z podatkami; określono również wysokość largicji, czyli kwot którymi hetmani dysponowali, a i ten przywiej ograniczono uprawnieniami koła generalnego. Hetmani czuwać mieli nad ilością cudzoziemców wśród oficerów i wielkością komputu uchwalonego na sejmie. Przysięga, którą mieli obowiązek złożyć, zobowiązywała ich ponadto nie tylko do trzymania granicy podczas sejmów elekcyjnych, ale także do nieprzystępowania do żadnej wyborczej fakcji. Wyrzekli się posługiwania wojskiem do celów prywatnych, stawiając na pierwszym miejscu obronę granic Rzeczypospolitej. Podczas rozruchów wewnętrznych przyrzekli nie przystępować do żadnej ze stron i korespondencji z postronnymi władcami ku swemu pożytkowi nie prowadzić. Przysięga kończyła się zobowiązaniem, aby „oficerów dysydentów z krzywdą katolików, tylu się w wojsku, ile katolików nie znajdowało" 54 .

I właśnie kwestia złożenia tejże przysięgi wywołała kolejny kryzys i opóźnienie $\mathrm{w}$ ratyfikacji traktatu. Hetmani odbyli audiencję u króla, uskarżając się na przymus złożenia przysięgi, co w ich mniemaniu dyskredytowało sam urząd i tytuł hetmański. August II odrzucał ich pretensje, grożąc przekazaniem buław osobom, które przystałyby na takie warunki ${ }^{55}$. Wówczas hetmani zaczęli działać na własną rękę: Pociej skupił wokół siebie część niezadowolonych oficerów litewskich oraz tych, którzy nie pomieścili się $\mathrm{w}$ nowym kompucie i myśleli o zawiązaniu nowego związku $^{56}$. W odpowiedzi August II wyraził gotowość przystąpienia do konfederacji, co byłoby równoznaczne z przejęciem przez niego władzy nad wojskiem. To z kolei nie znalazło poparcia rokoszan, którzy zażądali stanowczo, by w ciągu trzech dni hetmani złożyli przysięgę, $w$ innym wypadku uznawać będą buławy za wakujące ${ }^{57}$.

Wówczas hetmani chwycili się ostatniej szansy - zwrócili się o pomoc do swego najważniejszego protektora, księcia G.F. Dołgorukiego ${ }^{58}$. We-

\footnotetext{
Ibidem, s. 126-128.

Diariusz, k. 228.

Ibidem, k. 233.

Ibidem, k. 250.

58 J. Gierowski, „Opisanie”, s. 207.
} 
dług Józefa A. Gierowskiego mediator za późno spostrzegł, że opisanie buław rzeczywiście nie w pełni odpowiada interesom Moskwy i dlatego zgodził się poprzeć ich pretensje. Wystąpił ze skargą że go oszukano, dając mu do podpisania traktat spisany po łacinie - "czego on nie rozumie" - a hetmanów, których car ma w opiece swojej, na władzy opisano. Deklarował, że wojsk moskiewskich nie wyprowadzi z Rzeczypospolitej, dopóki „Hetmani nie będą ukontentowani w żądaniu swoim” ${ }^{59}$. Wystąpienie G.F. Dołgorukiego poruszyło i zbulwersowało nie tylko konfederatów, ale także plenipotentów królewskich, wszyscy bowiem wiedzieli, że kniaź kłamie, bo tłumaczenie traktatu na rosyjski od dawna posiadał. August II, mimo gróźb, stał na stanowisku odrzucenia jego postulatów i trzymania się przysięgi hetmanów. Konfederaci poszli dalej, wyrażając w ostrych słowach, że jemu nie do spraw "domowego porządku”, a i czasy, kiedy Polacy carów na moskiewskim tronie sadzali, mogą wrócićc ${ }^{60}$. Ostatecznie książę mediator ustąpił i nie wracał już do kontrowersyjnej sprawy opisania urzędów hetmańskich - jedynie w liście z 1 stycznia 1717 r. prosił Ledóchowskiego o „instancję” dla hetmanów, ale i ta ostatnia próba spotkała się z odmowną odpowiedzią ${ }^{61}$.

Wreszcie 2 stycznia 1717 r. przystąpiono do przysięgi. Ceremonia odbywała się na Zamku Królewskim w obecności posłów zagranicznych, księcia mediatora, senatorów, ministrów i plenipotentów stanów skonfederowanych. Pierwsi przysięgali hetmani litewscy, powtarzając rotę czytaną przez księcia Karola Radziwiłła, kanclerza Wielkiego Księstwa Litewskiego. Pociej powtórzył tekst bez większego zażenowania, natomiast Stanisław Denhoff, hetman polny litewski, złożył po przysiędze protest na ręce kanclerza i oznajmił, że do ceremoniału tego został przymuszony. Hetmani koronni, ze względu na słaby stan zdrowia, otrzymali pozwolenie królewskie na złożenie roty $\mathrm{w}$ domach $\mathrm{w}$ obecności posłów konfederackich. Jednakże kiedy delegacja przybyła do Sieniawskiego, ten zanegował składanie przysięgi przy rokoszanach. Ostatecznie plenipotenci zgodzili się opuścić dom Sieniawskiego, który dopiero wówczas złożył jurament. Trudniej było nakłonić do powtórzenia roty hetmana polnego koronnego Stanisława Rzewuskiego, ale i on po wcześniejszym zastrzeżeniu, że do przysięgi został przymuszony i że składa ją jako hetman, a nie szlachcic - wypełnił ją ${ }^{62}$. W tym samym czasie na Pradze odbywała się sesja, na której ksiądz Fredro jeszcze raz nakłaniał konfederatów do złagodzenia treści juramentu. Wreszcie, kiedy nadeszły wieści o zakoń-

59 Diariusz, k. 246v.

60 Ibidem.

61 A. Prochaska, op. cit., s. 655.

62 Por. Diariusz, k. 115-116; Dziennik, s. 241-245. 
czeniu ceremonii, konfederaci zgodzili się na usunięcie z traktatu punktu zakazującego hetmanom udziału w elekcji, pod warunkiem wszakże mianowania na ten okres regimentarzy, którzy zastąpiliby ich przy wojsku ${ }^{63}$. Zmiana ta ostatecznie nie została wprowadzona do konstytucji.

Pod obrady powróciła też kwestia „opisania” praw dysydentów i to w zupełnie nowej treści. W liście do swoich komisarzy konfederackich Ledóchowski zalecił, by tolerancja religijna, a nie procesy $\mathrm{z}$ różnowiercami - takie jak z Gdańskiem - była w państwie, bo „zda się być Rzeczypospolitej naszej potrzebniejsza, niżeli dewocja, którą zawsze, ile w Rzeczypospolitej naszej nosim" ${ }^{\prime 64}$. Czy marszałek zaczął przedkładać dobro ogólnopaństwowe nad interesy partykularne - trudno stwierdzić jednoznacznie. Potwierdził jednak swoją wolę, gdy plenipotenci w jego imieniu zażądali, aby prawa dysydentów według starych praw i zwyczajów były pozostawione, a nadto dano postulat salvo permaneant, a więc zachowania tychże praw na przyszłość. Konfederaci nadmienili także, że nie może być dyskryminacji dysydentów nobilitowanych, z tego względu, że cała szlachta jest równa przed sądem ${ }^{65}$. W dniu, w którym marszałek generalny składał swoją funkcję, wyszedł z propozycją dokonania rewolucji $\mathrm{w}$ dotychczasowych ustaleniach i opracowania na nowo projektu obejmującego całościowo sprawy religijne - pod tytułem: Dissidentium in fide orthodoxa ${ }^{66}$. Odpowiedź królewska był lakoniczna - potwierdzono jedynie, że pokój i bezpieczeństwo będzie takie, jak w traktacie zapisano i nic ponadto ${ }^{67}$. Nie zadowalało to tarnogrodzian, którzy jeszcze dwukrotnie postulowali zmiany w projekcie religijnym. Ostatecznie zachowano pierwotny tekst gradusów, nie wprowadzając żadnych zmian. W całej tej dyskusji intryguje fakt zmiany stanowiska konfederatów w stosunku do dysydentów po podpisaniu traktatu warszawskiego. O ile bowiem początkowo rokoszanie stali zdecydowanie po stronie księdza biskupa, o tyle później ewoluowali ku postawie, jeśli nie otwarcie dysydenckiej, to przynajmniej antyklerykalnej. Trudno tu jednak dopatrywać się głębszych pobudek religijnych, nakazujących ewangeliczną miłość bliźniego. Górę wzięły raczej względy racjonalne, mogła to być zemsta za wcześniejszą postawę Szaniawskiego, sprzeciwiającego się stanowczo obłożeniu leżami zimowymi dóbr duchownych.

63 Diariusz, k. 116.

64 Kopia listu Ledóchowskiego do pp. Komisarzy z Węgrowa 6 listopada 1716, w: Diariusz, k. $194 \mathrm{v}$.

65 Diariusz, k. 239-239v, 252.

66 Punkty z sesji dnia 23 stycznia 1717, w: Diariusz, k. 136, 139.

67 Respons na te punkty z kancelarii W. Krney dany w Warszawie dnia 26 stycznia 1717, w: Diariusz, k. 136-136v. 
Na temat formy sejmu mającego kończyć konfederację tarnogrodzką obie strony wypowiedziały wiele słów, nie dochodząc jednak do wspólnej konkluzji. Uzgodniono jedynie, aby sejm ad modum konfederacji gołąbskiej odbywał się oraz żeby konsyliarze i marszałkowie konfederaccy otrzymali prawa posłów - rezygnując tym samym z odbywania sejmików poselskich $^{68}$. Sejm 1673 r. (o którym mowa) odbywał się w ten sposób, że najpierw zwołano walną radę do Warszawy, a drugą - przeciwników konfederacji - do Łowicza, następnie na tajnych konferencjach przygotowywano traktat, który przeczytano jako gotową konstytucję na sejmie. Za tego rodzaju rozwiązaniem opowiadały się początkowo obie strony, choć konfederaci zawsze zaznaczali, że chcą sejmu, którego obrady trwałyby co najmniej „dwie niedziele”. Później wysunęli także postulat sejmu zwyczajnego z prawem głosu, a to ze względu na niezadowolenie $\mathrm{z}$ niektórych postanowień traktatowych, m.in. rezygnacji z „opisania kluczy podskarbińskich". Szembek przychylił się do większości wysuniętych wówczas postulatów, jednak co do zakończenia konfederacji stanowczo zaznaczył, że sejm musi być nadzwyczajny, chociaż z zapewnieniem starej formy obrad ${ }^{69}$.

Dalsze rozmowy przerwano aż do połowy grudnia, kiedy to chorąży płocki reprezentujący stany skonfederowane zażądał, aby na sejmie można było "przymawiać” do konstytucji, mimo że na wzór gołąbskiej będzie się odbywać ${ }^{70}$. W dalszym ciągu jednak strona królewska trzymała się ustalonych zasad $\mathrm{w}$ obawie, by zgoda na zmiany nie doprowadziła do zniweczenia zatwierdzonego już traktatu. Z ramienia skonfederowanych wystąpił wówczas główny plenipotent Ledóchowskiego (Józef Potocki), proponując przyjęcie trzech postanowień rady konsyliarskiej, wśród których najważniejsze, o sejmie, aby był cum plena facultate vocis activus $^{71}$. Dwór uparcie pozostawał na stanowisku, iż sejm, który idzie „extraordynaryjna drogą", nie pozwala na publiczne odzywanie się w sprawach prywatnych - czego żądają związkowcy. Tak niewzruszona postawa dworu nie uspokoiła rokoszan, którzy już parę dni później dążyli do ponownego przyjęcia (przez komisarzy królewskich) formy sejmowania z głosem wolnym. Powtarzali swe propozycje przez kolejne dni obrad, napotykając niewzruszony opór dworu ${ }^{72}$.

\footnotetext{
68 Por. W. Stanek, Konfederacje, s. 187.

69 Respons od [...] Prymasa Korony Polskiej i W. Ks. Lit. dany w Warszawie 29 listopada 1716, w: Diariusz, k. 207.

70 Diariusz, k. 229.

71 Ibidem, k. 233.

72 Ibidem, k. 239, 251v.
} 
W styczniu dyskusja przeszła na inne tory, tarnogrodzianie wysunęli bowiem postulat zakończenia konfederacji nomenklaturą związkową, a szczególnie słowami: „vim et robur legis mającej"73. Biskup kujawski wyczuł intencje rokoszan i w imieniu króla poinformował, że August II także myślał o sejmie zwyczajnym, ale interes Rzeczypospolitej wymagał tego, by zastosować nadzwyczajną procedurę i jedynie na przeczytaniu konstytucji zakończyć obrady. Proponowanie nomenklatury konfederackiej - replikował Szaniawski - jest podstępem, pod którym związkowcy chcą zmienić na sejmie wypracowane już projekty i wprowadzić zamieszanie w Rzeczypospolitej ${ }^{74}$.

30 stycznia 1717 r. zeszli się na wspólnej sesji deputaci obu stron, senatorowie i konsyliarze wojewódzcy celem wyprawienia posłów do księcia G.F. Dołgorukiego z wiadomością o zakończeniu rozmów i ratyfikacji traktatu. Delegacja miała również domagać się od niego, jako mediatora - przez którego ręce miała nastąpić wymiana dokumentów - ordynansu do wojsk moskiewskich z rozkazem ewakuacji z granic Rzeczypospolitej. Następnie wszyscy deputowani przystąpili do podpisywania konstytucji i jeszcze tego samego dnia nastąpiła ratyfikacja, czyli wymiana dokumentów traktatowych; plenipotenci dworu przekazali konfederatom ordynanse Augusta II do wojsk saskich, żądające w czternaście dni od przyjęcia tegoż rozkazu przejścia poza granice Rzeczypospolitej. Na koniec pożegnano G.F. Dołgorukiego opuszczającego obrady warszawskie jeszcze przed rozpoczęciem sejmu. Wyjeżdżając, obiecał posłom wymarsz wojsk rosyjskich w ciągu dwudziestu pięciu dni, z zastrzeżeniem, że oddziały generała Bauera stacjonującego w Wielkopolsce będą musiały poczekać na ordynans od samego cara ${ }^{75}$. Następnego dnia feldmarszałek Flemming, koniuszy Wielkiego Księstwa Litewskiego, już jako komendant gwardii królewskiej złożył przysięge „,super fidelitate JKMści y Rzpltey"76.

W dniu 1 lutego 1717 r. odbył się sejm extraordynaryjny "bez głosów”, który przeszedł do historii Polski, jako „sejm niemy”. Inaczej bowiem, jak wyrażali się plenipotenci dworu, nie można było trafić do końca i utrzymać uchwały ",tak zbawienne in publicam chyba zabroniwszy mówić tym, którzy sarkali [...] zaczym wszyscy zgodnie z wzajemnego upodobania i zezwolenia na to się zgodzili [...], aby ten sejm na samym przeczytaniu konstytucji [...] bez rozdawania głosów odprawił się"77.

\footnotetext{
Ibidem, k. 117.

Ibidem, k. $118 \mathrm{v}$.

Ibidem, k. 141.

6 Ibidem.

77 Ibidem, k. 143.
} 
Ceremoniał otwarcia miał miejsce o godzinie dziewiątej w sali senatorskiej zamku warszawskiego, w obecności króla, trzydziestu sześciu senatorów oraz deputowanych konfederackich, którzy przebywali tam w charakterze posłów ziemskich. Po powitaniu monarchy przez marszałka Stanisława Ledóchowskiego i odpowiedzi od tronu kanclerza wielkiego koronnego, przystąpiono do całowania ręki królewskiej. Po tym akcie miano odczytać konstytucje, gdy nieoczekiwanie i wbrew wcześniejszym umowom o głos poprosili: hetman wielki koronny Adam Sieniawski oraz hetman polny koronny, a zarazem wojewoda podlaski Stanisław Mateusz Rzewuski, który stwierdził, że "sejmom a osobliwie pacificationis nie jest zwyczaj bywać niemym i głuchym"78 - spotkało się to ze zdecydowanym sprzeciwem zgromadzonych posłów i dyscypliny dotrzymano ${ }^{79}$. Mimo to, jeszcze kilkakrotnie niektóre znaczniejsze osobistości próbowały wystąpić na forum parlamentarnym, wśród nich starosta starodubowski Wołek, reprezentujący dysydentów ${ }^{80}$. Nawet po przystąpieniu do odczytywania konstytucji dwukrotnie przerywali je: pisarz polny koronny Jan Sapieha i wojewoda krakowski Janusz Wiśniowiecki. Wystąpienia te nie wpłynęły jednak na dalszy tok obrad i po zakończeniu referowania konstytucji koronnych zaraz też odczytano litewskie - już bez żadnych przerw. Na koniec i arcybiskup gnieźnieński Stanisław Szembek prosił o głos, z uwagi na obietnicę daną mu rzekomo przez konfederatów, którzy ze względu na godność prymasowską nie mieli mu tego bronić. Ale i tym razem posłowie odmówili; w konsekwencji urażony prymas, na znak protestu, opuścił salę sejmową i już do niej nie powrócił81.

Po wypadkach sejmowych udzielono audiencji poselstwu od wojsk koronnych i litewskich, uskarżano się Augustowi II, że w zamian za zasługi dla Rzeczpospolitej otrzymali mało zapłaty i rozkaz „,zwinięcia chorągwi". Król ze swej strony obiecał punktualną płacę, która in futurum nastąpić miała. Na zakończenie głos zabrał Ledóchowski, żegnając króla, dziękował mu za ojcowskie starania uspokojenia publicznego, nadmieniając jednak, by „ewakuacji wojsk saskich zadość uczynił”82. Po skończonej ceremonii August II, senat i posłowie udali się do kościoła św. Jana „na Te Deum Laudamus, gdzie Panu Bogu za tak szczęśliwie zakończone Ręki Jego Dzieło oddane Gratiarum Actiones" ${ }^{\prime 3}$.

78 A. Link-Lenczowski, Stanistaw Mateusz Rzewuski h. Krzywda, w: Polski Stownik Biograficzny, t. 33, https://www.ipsb.iolab.pl/a/biografia/stanislaw-mateusz-rzewuski-h-krzywda [dostęp: 3 III 2018].

79 Diariusz, k. $143 \mathrm{v}$.

80 Dziennik, s. 278-279.

81 Diariusz, k. 144.

82 Ibidem.

83 Ibidem, k. $144 \mathrm{v}$. 
Traktat warszawski uznany został jako prawo kardynalne na mocy postanowień samego traktatu ${ }^{84}$. Zaliczono go więc w poczet praw fundamentalnych Rzeczypospolitej na równi z Artykułami henrykowskimi. W preambule konstytucyjnej zagwarantowano powrót „ad antiquum statum liberae Reipublicae", utrzymując tym samym prawo szlachty do veta, a także prerogatywy urzędów duchownych, marszałkowskich, pieczętarskich, podskarbich i hetmańskich. Najważniejszy jednak wydaje się być zapis, w którym zachowuje się wszelkie prawa i obowiązki monarchy, ale tylko jeśli są one zgodne i aprobowane przez stany Rzeczypospoliteje ${ }^{85}$. Traktat miał na celu nie tyle pogodzenie wolności szlacheckiej z majestatem królewskim, co powrót do przywilejów "stanu sarmackiego" według dawnego zwyczaju i kształtu. Dlatego też większość postanowień w nim zawartych dotyczyła aktualnych wówczas, lecz niemających trwałego znaczenia zagadnień. Przywrócenie „nowego" ustroju to nic innego, jak głoszony przez konfederatów postulat naprawy exorbitancji, czyli sprowadzenia na drogę prawa i porządku złamanych prerogatyw stanu rycerskiego. Od dawna bowiem jednym z kanonów „złotej wolności" było przekonanie, że ustrój Rzeczypospolitej, jeśli nie jest idealny, to przynajmniej najlepszy z możliwych, a wszelka niesprawiedliwość, jaka się dzieje, wychodzi od monarchy, który albo źle rządzi, albo pozwala na złe egzekwowanie prawa ${ }^{86}$.

Naczelna zasada traktatu, możliwe największe ograniczenie władzy królewskiej poprzez rozszerzenie praw szlacheckich, zapobiegła z góry wszelkim próbom wprowadzenia jakiejkolwiek innej formy rządów niż istniejącej. Poprzez nową formę rozumiano absolutyzm, który według konfederatów chciał wprowadzić dwór Wettyna w Polsce ${ }^{87}$. Dlatego też traktat wymienia szereg konstytucji uprzednio już obowiązujących, zapewne w celu podkreślenia ich wagi i specjalnej aktualności, a te, które teraz zostały ustanowione, powierza się pieczy ministrów, by prawa i Pacta conventa były przestrzegane. Do postanowień przejściowych mających jedynie zachować dotychczasowe status quo zaliczyć można ewakuację wojsk saskich, sądzenie adherentów szwedzkich czy rozwiązanie samych

84 VL, t. 6, s. 132.

85 Ibidem, s. 113.

86 S. Grodziski, W rocznice "Sejmu Niemego" (1717-1967), „Studia Historyczne” 1967, 10, 3-4, s. 21.

87 Manifest skonfederowanych z 13 czerwca 1716, w: Diariusz, k. 22-23v; na temat ciągłych obaw szlachty co do absolutystycznych dążeń Augusta II zob. A. Grześkowiak-Krwawicz, Regina libertas. Wolność w polskiej myśli politycznej XVIII wieku, Gdańsk 2006; P. Buchwald-Pelcowa, Satyra czasów saskich, Wrocław 1969. 
konfederacji. Mimo że mogły one uchodzić za wynik kompromisu, w którym August II wyrzekł się swych planów absolutystycznych, a szlachta dążeń detronizacyjnych, to stanowią one dowód zwycięstwa tarnogrodzian, gdyż czynią zadość ich głównym postulatom ${ }^{88}$. Restitutio in integrum było podstawowym hasłem szlacheckim związanym $\mathrm{z}$ reformami sejmu niemego. Pod tym postulatem kryło się jednak coś więcej niż tylko zwycięstwo nad grabieżami i uciskiem wojsk saskich; konfederaci poważnie traktowali ustrój demokracji szlacheckiej, czemu dali wyraz w zapisie konstytucyjnym przeciw zbrodniarzom stanu i wszystkim łamiącym traktat warszawski ${ }^{89}$. Na mocy artykułu trzeciego miano powołać specjalne sądy z mocą i władzą sądów sejmowych, które trwałyby do końca wojny szwedzkiej (tj. wojny północnej). Nie zostały one jednak nigdy stworzone - jak zauważa Stanisław Grodziski - być może dlatego, że stanowić mogły narzędzie w umacnianiu władzy królewskiej ${ }^{90}$.

Wśród współczesnych pisarzy politycznych przebieg rozmów traktatowych i sejmu niemego został oceniony krytycznie i to nie $\mathrm{z}$ racji obalenia absolutystycznych - jak ciągle mniemano - dążeń Augusta II, ale przede wszystkim z faktu umacniania w Rzeczypospolitej wpływów rosyjskich, czego pierwszym objawem miało być osłabienie liberum veto, które na czas rokowań zostało zawieszone ${ }^{91}$. Biorąc pod uwagę te głosy, należy pamiętać, że pacyfikacja wewnętrzna była w dużej mierze rezultatem nacisków Moskwy, reprezentowanej w osobie kniazia G.F. Dołgorukiego. Rosja - jak można było przypuszczać - nie była zainteresowana całkowitym zbliżeniem stanów szlacheckich z królem, gdyż mogło ono doprowadzić do faktycznego skonsolidowania głównych sił politycznych państwa i być może zahamować, a nawet wyeliminować możliwość interwencji carskiej w wewnętrzne sprawy Rzeczypospolitej. Jednakże mediator, jak się okazało, nie miał większych problemów z realizacją dyrektyw Piotra I; antagonizm między monarchą a skonfederowanymi był tak silny, że nawet znalezienie kompromisu i położenie kresu istniejącym rozbieżnościom nie mogło na stałe zapobiec wzajemnej nieufności.

Dzięki mediacji G.F. Dołgorukiego konfederaci odnieśli sukces w realizacji swoich głównych postulatów: zaprzestania grabieży i wymarszu wojsk saskich oraz ograniczenia kompetencji dworu ${ }^{92}$. Bardzo szczegółowo opisano tryb ewakuacji wojsk elektorskich z równoczesnym zakazem

\footnotetext{
88 Z. Radwański, Prawa kardynalne w Polsce, Poznań 1952, Studia nad historią prawa polskiego, 16, 1, s. 33.

$89 V L$, t. 6, s. 121

90 S. Grodziski, op. cit., s. 22.

91 H. Olszewski, Doktryny, s. 166.

92 Por. Articulus Finalis, w: Diariusz, k. 182-182v.
} 
wprowadzania ich kiedykolwiek. Ministrowie sascy wyłączeni zostali z kierowania sprawami dyplomatycznymi państwa; ale ograniczenia ministerialne dotyczyły także Polaków, ich urzędy senatorów-rezydentów zostały szczegółowo określone ( $w$ nadziei odizolowania monarchy od magnackich doradców $)^{93}$. Przez opisanie rad senatu nie tylko przekreślono dotychczasowe plany Augusta II związane z tą instytucja, ale ograniczono jej rzeczywiste wpływy na rządy w Polsce ${ }^{94}$. Decyzje powzięte na radzie miały być wpisywane do ksiąg kamelarii koronnej i ksiąg grodzkich oraz przedstawiane na sejmikach przedsejmowych. Poza tym rezydenci nie mogli swoimi uchwałami wkraczać w kompetencje sejmów, co było niemożliwe, jako że większość decyzji - głównie o charakterze administracyjnym - miała znaczenie podobne do sejmowych. Badania Jarosława Porazińskiego ${ }^{95}$ i Mariusza Markiewicza ${ }^{96}$ wykazały, że po roku 1717 rady senatu nie odgrywały już większej roli, a ich uchwały miały charakter rutynowy.

Inaczej przedstawiała się sytuacja z uchwaleniem reform skarbowo-wojskowych; rokowania traktatowe wykazały całkowity brak kompetencji strony konfederackiej, która nie ogłosiła żadnego programu czy choćby zarysu rozwiązań ustrojowych dotyczących wojska i budżetu. Wręcz przeciwnie, od początku pojawienia się problemu oddała ona inicjatywę stronie dworskiej, rezygnując z wszelkich pretensji do tworzonego projektu ${ }^{97}$. Uchwały sejmowe przewidywały utworzenie stałej armii osiemnastotysięcznej w Koronie i sześciotysięcznej na Litwie. Jak się okazało, ograniczenie komputu odpowiadało każdej ze stron, konfederaci widzieli w tym zmniejszenie obciążeń podatkowych, a Augustowi, który i tak nie widział już realnych szans na zrealizowanie aukcji, miało ułatwić pozyskanie bogatej szlachty z równoczesnym ograniczeniem znaczenia hetmanów. Możnowładcy z kolei zdawali sobie sprawę, że zreformowane wojsko będzie w większym stopniu uzależnione od króla niż od nich, dlatego nie oponowali przed zmniejszeniem jego liczby ${ }^{98}$. Należy zwrócić uwagę na fakt, że w budżecie uchwalonym na sejmie 1717 r. nie przewidziano osobnego funduszu na pensje dla oficerów, podoficerów i rzemieślników wojskowych. Tym samym musiano ich opłacać z sum przeznaczonych na utrzymanie szeregowych, co zmniejszało faktyczną

\footnotetext{
93 Por. Rezydenci do Boku JKrMści 1 lutego 1717, w: Diariusz, k. 142-142v.

94 J. Poraziński, Funkcje polityczne i ustrojowe rad senatu w latach 1697-1717, „Kwartalnik Historyczny" 1984, 51, 1, s. 43.

95 Idem, Ordo intermedius? Kilka uwag o politycznej roli senatu w XVII i XVIII wieku, w: Między wielka, s. 217-224.

96 M. Markiewicz, Rady senatorskie Augusta II (1697-1733), Wrocław 1988, s. 97.

97 Dziennik, s. 183.

98 Jan Wimmer, op. cit., s. 433.
} 
ilość ludzi pod bronią. Poza tym projektodawcy nie wnieśli żadnych poprawek $\mathrm{w}$ kwestii unowocześnienia formacji regimentów i przystosowania ich do ówczesnych potrzeb pola walki. W dalszym ciągu duży procent stanowiła husaria i pancerni, a zbyt mało piechoty i dragonii, nie mówiąc o artylerii, której na Litwie w ogóle nie przewidziano ${ }^{99}$.

Dwór Augusta II nazbyt wiele uwagi przykładał do roli, jaką spełniała fakcja szwedzka w konfederacji tarnogrodzkiej - nieproporcjonalnie do ich prawdziwych możliwości. Do końca rozmów lubelskich i warszawskich plenipotenci królewscy forsowali punkty bezpośrednio lub pośrednio związane ze stronnictwem Leszczyńskiego, czasami wręcz w ogóle niezwiązane z meritum traktatu. I tak w projekcie z lipca $1716 \mathrm{r}$. około 1/4 postulatów strony królewskiej dotyczyła zabezpieczenia monarchy przed niebezpieczeństwem szwedzkim ${ }^{100}$. Wynikało to bądź ze złego stanu wiedzy na temat faktycznej sytuacji stanisławowczyków, bądź stanowiło wyrachowaną grę polityczną, w której wyeksponowanie ponad miarę siły partii leszczyńskiego było kartą przetargową dla uzyskania lepszych wyników rozmów. To drugie wydaje się jednak mniej prawdopodobne, ponieważ $\mathrm{w}$ traktacie warszawskim, mimo ustanowienia amnestii generalnej, zapisano szczegółowo, że „ostrzega się [...] osobliwie, iż beneficio amnestii Stanisławowi Leszczyńskiemu, tym którzy z nim trzymając za granicą się bawią, jeżeli w trzech miesiącach od daty podpisu niniejszego traktatu do ciała Rzpltey nie powróca, cieszyć się ani zaszczycać nie będzie godziło, dla tego [...] przeciwko nim in legibus expressarum, reservatur"101. Wynika z tego jasno, że August II poważnie podchodził do groźby faktycznego wpływu emigracji banderskiej na bieg wydarzeń politycznych w kraju. Upewnił go w tym jeszcze podskarbi Jan Przebendowski, który większość czasu (w okresie rozmów lubelskich) przebywał w Gdańsku, skąd słał listy do Warszawy, informując o coraz większym dopływie żołnierzy szwedzkich do oddziałów Gniazdowskiego $^{102}$. W odpowiedzi konfederaci przedstawiali w ramach kondycji do traktatu zapewnienia, że co prawda stronnicy Leszczyńskiego i sami Szwedzi znajdowali się w związku, ale nie stanowili znacznej siły ani tym bardziej nie mieli żadnego wpływu na charakter konfederacji, która wyrosła przecież z ruchu ogólnoszlacheckiego ${ }^{103}$.

99 Zob. Komput Generalny Wojska Koronnego [...] uformowany anno 1716, w: Diariusz, k. 227-227v.

100 Kondycje do traktatu [...] z 23 lipca 1716, w: Diariusz, k. 28-29v.

101 VL, t. 6, s. 131.

102 Dziennik, s. 170-172.

103 Ibidem, s. 184. 
Problemem nierozwiązanym przez historiografię polska, a tu jedynie zaznaczonym, jest kwestia stosunku konfederatów tarnogrodzkich do uchwał antydysydenckich, zawartych w traktacie warszawskim. Z przebiegu rozmów plenipotentów obu stron, przynajmniej tych z listopada 1716 r., wynika jasno, że zarówno biskup Szaniawski, jak i rokoszanie stali zdecydowanie na gruncie nieprzyznawania różnowiercom całkowitego równouprawnienia, lecz zachowania jedynie tych praw, które wcześniej zostały przyjęte ${ }^{104}$. Jednakże po podpisaniu traktatu rada konsyliarska (głównie marszałek Stanisław Ledóchowski) zwróciła uwagę na zbyt rygorystyczne potraktowanie sprawy dysydentów i w ogóle wyolbrzymienie kwestii religijnych w punktach projektów ${ }^{105}$. Ledóchowski wzywał do ustanowienia większej tolerancji, szczególnie w sprawach Gdańska, na który wrogim wzrokiem patrzył cały ówczesny kler z uwagi na posiadłości, jakie tam utracił. Marszałek proponował więc odłożenie problemu tolerancji, zdając sobie sprawę, że wygrywa na tej dyskusji jedynie biskup kujawski dążący do skłócenia samych konfederatów, co zresztą niejednokrotnie mu się udawało. Nie bez znaczenia był też fakt, że właśnie $\mathrm{w}$ tym okresie miały miejsce rozmowy na temat leż zimowych dla wojska, a głównie udostępnienia dla nich dóbr kościelnych - o czym już była mowa - i czemu zdecydowanie sprzeciwiał się Szaniawski. Może właśnie to zdecydowało o zmianie zdania konfederatów na temat causae religionis i dokonanych już w traktacie zapisów.

Jedynym historykiem, który zajął się tą problematyką, był Józef Feldman ${ }^{106}$. Stał on na stanowisku odmiennym od wyżej prezentowanego. Uważał, że pierwszy impuls do ograniczeń wyznaniowych wyszedł z łona skonfederowanych i dopiero po rozwinięciu przez różnowierców agitacji wśród wpływowych osób Wielkopolski i Litwy nakłoniono marszałka konfederacji do zmiany poglądów. Niestety racje te, choć prawdopodobne, nie posiadają podstawy źródłowej, a przynajmniej autor jej nie podaje, przez co nie można jej zweryfikować. Faktem jest jednak, że na sejmie niemym doszło do próby złożenia protestacji przez przedstawiciela dysydentów (wspomnianego wcześniej) chorążego starodubowskiego Wołka ${ }^{107}$. Mogło to świadczyć o pewnych wpływach tej grupy wyznaniowej w wyższych warstwach społecznych, ale nie na tyle mocnych, by dopuścić do głosu na sejmie, gdzie nawet prymas musiał milczeć.

Jacek Staszewski zwracał uwagę, że dopiero po sejmie niemym 1717 r., a przed sejmem zwyczajnym 1718 r., nastąpiły wydarzenia (nie do końca

\footnotetext{
104 Copia projektu Religionis, w: Diariusz, k. 160v-161.

105 Copia listu [...] Ledóchowskiego do [...] komisarzy, w: Diariusz, k. 194v.

106 J. Feldman, Sprawa dysydencka za Augusta II, „Reformacja w Polsce” 1924, 3, s. 91-93.

107 Diariusz, k. 143v.
} 
zresztą znane historiografii polskiej), które zaostrzyły wyraźnie politykę antyróżnowierczą. Wiązał on to między innymi ze wzrostem kultów dewocyjnych: koronacjami obrazów, z koronacją Panny Częstochowskiej na czele $^{108}$. Sejm roku 1718 przeszedł też do historii jako pierwszy, na którym z inicjatywy duchowieństwa ostatecznie i bezpowrotnie wykluczono z obrad parlamentarnych posła innowierczego - Andrzeja Piotrowskiego reprezentującego ziemię wieluńską.

Sejm niemy ma tyleż opinii o swoim znaczeniu dla historii Polski, co badaczy zajmujących się tą problematyką. Można powiedzieć, że zwolenników i przeciwników jego „przełomowej roli” w parlamentaryzmie polskim można podzielić po połowie. Najostrzej chyba ocenił go Michał Bobrzyński, pisząc, że Polska „ujrzała się taką jaką ją sejm pacyfikacyjny z roku 1717 utrzymał, bez żadnej wewnętrznej organizacji, bez energicznej władzy, bez odpowiedniego wojska i podatków, z zagrodzoną drogą wszelkiej w tym kierunku reformy". Inne kraje europejskie - według niego - szły dokładnie w kierunku odwrotnym: silna władza centralna była dysponentem bezwzględnie posłusznej administracji i wojska ${ }^{109}$. Jerzy Topolski dopowiadał, iż od sejmu utrwaliła się „krótkowzroczna praktyka szukania rosyjskiej protekcji dla wygrywania własnych celów wewnętrznych. Praktyka ta stanie się później, jak wiadomo, jednym z głównych czynników blokujących reformy państwa"110.

Jacek Staszewski z kolei postrzegał konfederację tarnogrodzką i sejm niemy w szerokim kontekście europejskim, wydarzenia polskie były częścią składową wojny północnej, a przede wszystkim częścią polityki międzynarodowej Piotra I Wielkiego. Car obawiał się, że nie jest w stanie w pełni kontrolować sytuacji w Rzplitej, stąd jego nadaktywna działalność dyplomatyczna dążąca do utrzymania Kraju Obojga Narodów w wewnętrznym niepokoju i permanentnej nieufności szlachty wobec króla. August II w oczach Piotra I był uznawany za „spiritus movens życia politycznego w państwie polsko-litewskim, a zwłaszcza za inicjatora reform mogących wzmocnić państwo i zagrozić jego sąsiadom. Niedopuszczenie Rzeczypospolitej i Saksonii do rokowań pokojowych [w Nystad] zmierzało do osłabienia ich pozycji na arenie międzynarodowej. Nikt bowiem nie chciał się wiązać z państwami pozostającymi w stanie wojny ze Szwecją"111.

\footnotetext{
108 J. Staszewski, Z listy najczęściej spotykanych błędnych mniemań na temat czasów saskich, „Przegląd Humanistyczny” 1996, 40, 1, s. 161.

109 M. Bobrzyński, op. cit., s. 382, 387.

110 J. Topolski, Polska w czasach nowożytnych. Od środkowoeuropejskiej potęgi do utraty niepodległości (1501-1795), Poznań 1994, Polska. Dzieje narodu, państwa i kultury, t. 2, s. 419.

111 J. Staszewski, Z listy, s. 159.
} 
Toruński historyk uważał ponadto, że sejm niemy, który po raz pierwszy w dziejach państwa ustalił stałe podatki na wojsko, tym samym spowodował inercję parlamentarną - „zanikła [bowiem] potrzeba odwoływania się do sejmu o ponowne ich uchwalenie". Teraz to rady senatu, kamery zarządzające królewszczyznami i rodząca się administracja centralna oraz lokalna podejmowały działania niewymagające uchwał sejmu. Parlament służył jedynie za probierz sił politycznych, „stawiano przed nim zagadnienia reformy państwa, ale $w$ jej urzeczywistnienie wierzono coraz mniej. Posłowie (wspierani nieraz z zagranicy) pilnowali, żeby żadna odmiana nie nastąpiła"112.

Historycy prawa skupili się na kwestiach formalno-prawnych i ustrojowych; według Jerzego Michalskiego sejm niemy nie przebiegał pod węzłem konfederackim, ale pod jego bezpośrednim, wręcz dyktatorskim wpływem, a przez to pod względem ustawodawczym był najefektywniejszym sejmem czasów saskich.

Praktyka sejmu „niemego" - konkluduje Michalski - w samych jego ustawach uznana za zupełnie wyjątkowe odstępstwo od właściwych form sejmowania, wzbudziła zrozumiałą niechęć i obawy wśród społeczeństwa szlacheckiego jako niebezpieczny precedens wiodący do zagłady „wolności”. Ponieważ jednak ustawodawstwo sejmu 1717 r. odpowiadało w gruncie rzeczy temu społeczeństwu, stąd opory przeciw jego akceptacji nie były zbyt silne, a późniejsze próby modyfikacji wychodziły głównie od hetmanów dotkniętych „opisaniem" ich urzędów ${ }^{113}$.

Stanisław Kutrzeba widział ten sejm jako wyjątkowy pod jeszcze jednym względem, a mianowicie uchwalono na nim pierwszy budżet państwa uwzględniający przychody i wydatki (na wojsko). Poza tym w kwestiach formalnych - dla ułatwienia i przyspieszenia obrad - wprowadził on instytucję delegacyj, czyli komisji sejmowych opracowujących ustawy (niejako w imieniu całego sejmu) i później po wysłuchaniu przez ogół posłów w całości były on przyjmowane lub odrzucane. Najlepszym tego przykładem poza sejmem niemym był sejm czteroletni i uchwalenie Konstytucji 3 Maja ${ }^{114}$. Młodsze pokolenie historyków prawa zwraca uwagę na ograniczenie „rządów sejmikowych”, czyli pozbawienie kompetencji samorządu ziemskiego w kwestiach skarbowych i wojskowych. Paradoksem legislacyjnym sejmu niemego była też decyzja o zakazie - in spe - zawiązywania konfederacji szlacheckich, czego z oczywistych względów nie dotrzymano, skoro rokosz powszechnie uznawano za

112 Idem, Czasy, s. 70.

113 J. Michalski, Sejm w czasach saskich, w: Historia sejmu polskiego, t. 1, Do schyłku szlacheckiej Rzeczypospolitej, red. idem, oprac. J. Bardach et al., Warszawa 1984, s. 332-333.

114 S. Kutrzeba, Historia ustroju Polski w zarysie. Korona, Poznań 2001, s. 180-182. 
przejaw demokracji bezpośredniej i, co najważniejsze, korygujący wady rządów królewskich ${ }^{115}$.

\section{$* * *$}

Parafrazując słowa Konstantego Jarochowskiego, można zaryzykować uproszczoną tezę, że konfederacja tarnogrodzka była nieszczęśliwym zbiegiem okoliczności, a jej początki, przyczyny, pobudki i cele były czyste i uczciwe. Przyczyniła się jednak do zyskania większego i trwalszego wpływu cara Piotra I na sprawy polskie.

Wydaje się, że prawdziwym zarzewiem konfliktu inter maiestatem et libertatem był problem pojawiających się co jakiś czas na polskim terytorium wojsk saskich, a szczególnie utrzymanie finansowe i utrzymanie porządku tychże wojsk. Już po koronacji w $1697 \mathrm{r}$. pojawiły się pierwsze problemy z żołdactwem saskim grabiącym polskie dobra, bo nieopłaconym na czas ze skarbu elektorskiego, a stacjonującym w Koronie od czasu zwycięstwa elekcyjnego ${ }^{116}$. Po pokoju karłowickim 1699 r. ponownie miały zwinąć swoje chorągwie, bowiem zagrożenie tureckie minęło, tymczasem August znalazł pretekst, by zatrzymać je i przesunąć na granicę północno-wschodnią, niby dla pacyfikacji niepokojów na Litwie (w czym szlachta zgadzała się), a w rzeczywistości dla realizacji nowego planu - zajęcia szwedzkich Inflant. Pierwsze niepowodzenia w wojnie północnej przekształciły się szybko w drugi „potop”, dopełnieniem klęski stała się bitwa pod Kliszowem (z 1702 r.), na którą spieszyły nowe regimenty saskie. Wojna ta - pierwsza w XVIII w. na ziemiach polskich - zamiast zysków, przyniosła niepowetowane straty: polityczne dla dworu i gospodarcze dla szlachty.

W Polsce przez najbliższych kilka lat będzie prowadzony - jak to nazywano - taniec goniony armii szwedzkiej za saska, za Szwedami szły natomiast pułki rosyjskie. Ten sposób prowadzenia wojny bardziej przyczyniał się do wyniszczania kraju na szlakach przemarszów niż wszystkie dawniej prowadzone wojny. Takie tereny, jak np. Kujawy, po których parokrotnie przemieszczały się różne armie, były rujnowane doszczętnie. Rozprzestrzeniające się tam zarazy dopełniały dzieła zniszczenia, sprawiając, iż w okresie tej wojny straty wszelkiego rodzaju przekroczyły dotychczasowe doświadczenia ${ }^{117}$.

Tak więc konflikt na linii król - poddani miał zdecydowanie podłoże ekonomiczne, bardziej niż polityczne, co w konsekwencji doprowadziło

115 J. Bardach, B. Leśnodorski, M. Pietrzak, Historia ustroju i prawa polskiego, Warszawa 1993, s. 225-226.

116 J. Staszewski, August II na polskim, s. 291.

117 Ibidem, s. 299. 
także do zawiązania konfederacji tarnogrodzkiej, chociaż niemały tu wpływ miały także wojska koronne, jawnie niechętne komputom saskim. Ostatecznie sejm niemy, który kończył wojnę domową i który był kompromisem niezadawalającym żadnej ze stron - jak każda prowizorka - stał się fundamentem ustrojowym istniejącym do końca panowania Wettynów w Rzplitej. Król zaniechał reform i jak zauważył gorzko jego powiernik - Jakub Flemming - rozpoczął się okres "łagodnych rządów”"118.

Jerzy Topolski doszukując się źródeł negatywnej oceny epoki saskiej w polskiej historiografii, zauważył, że miała ona swe początki już w czasach stanisławowskich. „Król Staś” głosząc odnowę kraju i program niezbędnych reform - wręcz rewolucji społecznej i politycznej - potrzebował mitu upadłej ojczyzny w okresie poprzedzającym jego koronację. Tak zapoczątkowana została skuteczna, jak się okazuje, propaganda o saskich wiekach ciemnych, która stała się punktem odniesienia dla wieku oświecenia $^{119}$. Potwierdziły to badania Andrzeja F. Grabskiego ${ }^{120}$, Kazimierza Bartkiewicza ${ }^{121}$ i Jerzego Dygdały ${ }^{122}$; ten ostatni po przeanalizowaniu publicystyki politycznej doby oświecenia zauważył, że nasilenie negatywnych sądów $\mathrm{w}$ stosunku do Polski okresu saskiego wzrastało proporcjonalnie do zbliżających się dni chwały sejmu wielkiego. Kuźnica kołłątajowska ganiła en bloc zarówno politykę Augusta II, jego zaangażowanie $\mathrm{w}$ wojnę północną jak też konfederację tarnogrodzką - co wszystko razem skutkowało anarchizacją kraju i bezwładem organów państwowych, a tym samym słabością pozycji Rzplitej na arenie międzynarodowej ${ }^{123}$. Najbliższy Kołłątajowi Franciszek Salezy Jezierski pisał wprost: „Anarchia wzięła górę, został się czczy majestat dla królów, a naród bez rady i obrony"124. Krytyka była tym większa, im bardziej należało uwypuklić własne - tzn. autorów stanisławowskich - zasługi dla ratowania ojczyzny ${ }^{125}$. Droga do powstania "czarnej legendy” epoki saskiej została otwarta, a podążyli nią historycy XIX w., zarówno romantycy, jak i pozytywiści.

118 J. Staszewski, Czasy, s. 72.

119 J. Topolski, Czy istniała w Polsce epoka saska? Czyli metodologiczne implikacje periodyzacji historycznej, w: Między wielka, s. 38-39.

120 A.F. Grabski, Myśl historyczna polskiego oświecenia, Warszawa 1976.

121 K. Bartkiewicz, Obraz dziejów ojczystych w świadomości historycznej w Polsce doby Oświecenia, Poznań 1979.

122 J. Dygdała, U początków „czarnej legendy” czasów saskich, „Czasy Nowożytne” 2010, 23, s. 63-84.

123 Ibidem, s. 71

124 F.S. Jezierski, Wybór pism, oprac. Z. Skwarczyński, Warszawa 1952, s. 159.

125 J. Kurek, U schyłku panowania Augusta II. Z dziejów wewnętrznych Rzeczypospolitej (1729-1733), Katowice 2003, s. 47-48. 
$\mathrm{Na}$ koniec chciałbym umieścić cytat z pracy Andrzeja Link-Lenczowskiego Rzeczpospolita na rozdrożu 1696-1736, w której zawarł niezwykle trafną reasumpcję stanu badań nad postacią Augusta II w polskiej historiografii:

Można zaryzykować twierdzenie, iż nie było chyba w dziejach Rzeczypospolitej władcy, wokół którego narosłoby tyle opinii niewiele mających wspólnego z rzeczywistością, natomiast odwołujących się do emocji i negatywnych stereotypów, powielanych do niedawna w historiografii. Dopiero badania prowadzone w ciągu ostatnich trzydziestu lat przez kontynuatorów Kazimierza Jarochowskiego i Józefa Feldmana - Józefa A. Gierowskiego i Jacka Staszewskiego - wyjaśniły wiele nowych uwarunkowań działalności Fryderyka Augusta w Rzeczypospolitej i Saksonii. Prace te pozwalają rzetelnie wyważyć bilans osiągnięć i porażek władcy. W czasie panowania Augusta losy Rzeczypospolitej, jak nigdy wcześniej, uwarunkowane były wydarzeniami rozgrywającymi się $\mathrm{u}$ jej granic i szerzej - na wielkiej scenie niezwykle dramatycznych wydarzeń, których widownią miał się stać wkrótce zarówno wschód, jak zachód Europy ${ }^{126}$.

\section{REFERENCES (BIBLIOGRAFIA)}

\section{Manuscript sources (Źródła rękopiśmienne)}

Archiwum Państwowe w Toruniu, Akta Miasta Torunia, katalog II, rkps sygn. VI-24, Diariusz skonfederowanych na Kongresie Lubelskim de Anno 1716.

\section{Printed sources (Źródła drukowane)}

Dziennik konfederacji tarnogrodzkiej przeciw wojskom saskim, zawiazanej w Polsce 1715-1717, wyd. E. Raczyński, Poznań 1841.

Jezierski F.S., Wybór pism, oprac. Z. Skwarczyński, Warszawa 1952.

Otwinowski E., Dzieje Polski pod panowaniem Augusta II, wyd. A. Mułkowski, Kraków 1849.

Rzeczpospolita w dobie upadku, 1700-1740. Wybór źródet, oprac. i wstęp J. Gierowski, Wrocław 1955.

Volumina Legum, t. 6, wyd. J. Ohryzko, Petersburg 1860.

\section{Studies (Opracowania)}

Askenazy S., Wczasy historyczne, t. 1-2, Warszawa-Kraków 1902-1904.

Augustyniak U., Historia Polski 1572-1795, Warszawa 2008.

Bardach J., Leśnodorski B., Pietrzak M., Historia ustroju i prawa polskiego, Warszawa 1993.

Bartkiewicz K., Obraz dziejów ojczystych w świadomości historycznej w Polsce doby Oświecenia, Poznań 1979.

Bobrzyński M., Dzieje Polski w zarysie, Warszawa 1974.

Bogucka M., Dzieje kultury polskiej do 1918 roku, Wrocław 1991.

Brückner A., Dzieje kultury polskiej. Czasy nowsze do roku 1831, t. 3, Kraków 1931.

Buchwald-Pelcowa P., Satyra czasów saskich, Wrocław 1969.

Chrzanowski I., Reforma szkolna Konarskiego, w: I. Chrzanowski, Optymizm i pesymizm polski.

Studia z historii kultury, Warszawa 1971.

126 A. Link-Lenczowski, Rzeczpospolita, s. 6. 
Davies N., Boże igrzysko. Historia Polski, Kraków 2006.

Dygdała J., U początków „czarnej legendy” czasów saskich, „Czasy Nowożytne” 2010, 23.

Feldman J., Geneza konfederacji tarnogrodzkiej, „Kwartalnik Historyczny” 1928, 42, 3.

Feldman J., Sprawa dysydencka za Augusta II, „Reformacja w Polsce” 1924, 3.

Gierowski J.A., Konfederaci tarnogrodzcy wobec możliwości porozumienia szwedzko-rosyjskiego, w: Słowianie w dziejach Europy. Studia historyczne ku uczczeniu 75. rocznicy urodzin i 50-lecia pracy naukowej Profesora Henryka Łowmiańskiego, red. J. Ochmański, Poznań 1974.

Gierowski J.A., Między saskim absolutyzmem a złotą wolnością. Z dziejów wewnętrznych Rzeczypospolitej w latach 1712-1715, Wrocław 1955.

Gierowski J.A., "Opisanie” urzędów centralnych przez konfederatów tarnogrodzkich, w: O naprawe Rzeczypospolitej XVII-XVIII w. Prace ofiarowane Władystawowi Czaplińskiemu w 60. rocznice urodzin, red. J. Gierowski et al., Warszawa 1965.

Gierowski J.A., Traktat przyjaźni Polski z Francją w 1714 r. Studium z dziejów dyplomacji, Warszawa 1965.

Gierowski J.A., W cieniu Ligi Pótnocnej, Wrocław 1971.

Gierowski J.A., Leszczyński J., Dyplomacja polska w dobie unii personalnej polsko-saskiej, w: Polska stużba dyplomatyczna XVI-XVIII wieku, red. Z. Wójcik, Warszawa 1966.

Grabski A.F., Myśl historyczna polskiego oświecenia, Warszawa 1976.

Grodziski S., W rocznice „Sejmu Niemego" (1717-1967), „Studia Historyczne” 1967, 10, 3-4.

Grześkowiak-Krwawicz A., Regina libertas. Wolność w polskiej myśli politycznej XVIII wieku, Gdańsk 2006.

Hetmani Rzeczypospolitej Obojga Narodów, red. M. Nagielski, Warszawa 1995.

Historia dyplomacji polskiej, t. 2, red. Z. Wójcik, Warszawa 1982.

Jarochowski K., Wzięcie Poznania przez konfederatów tarnogrodzkich w dniu 24 lipca 1716 r., w: K. Jarochowski, Opowiadania Historyczne, Poznań 1860.

Korzon T., Odrodzenie w upadku. Wybór pism historycznych, Warszawa 1975.

Kriegseisen W., Samorząd szlachecki w Małopolsce w latach 1669-1717, Warszawa 1989.

Kurek J., U schyłku panowania Augusta II. Z dziejów wewnętrznych Rzeczypospolitej (17291733), Katowice 2003.

Kutrzeba S., Historia ustroju Polski w zarysie. Korona, Poznań 2001.

Link-Lenczowski A., Rzeczpospolita na rozdrożu 1696-1736, Kraków 1994.

Link-Lenczowski A., Stanisław Mateusz Rzewuski h. Krzywda, w: Polski Stownik Biograficzny, t. 33, https://www.ipsb.iolab.pl/a/biografia/stanislaw-mateusz-rzewuski-h-krzywda [dostęp: 3 III 2018].

Markiewicz M., Historia Polski 1492-1795, Kraków 2007.

Markiewicz M., Rady senatorskie Augusta II (1697-1733), Wrocław 1988.

Michalski J., Sejm w czasach saskich, w: Historia sejmu polskiego, t. 1, Do schyłku szlacheckiej Rzeczypospolitej, red. J. Michalski, oprac. J. Bardach et al., Warszawa 1984.

Miłosz C., Historia literatury polskiej, Kraków 2010.

Olszewski H., Doktryny prawno-ustrojowe czasów saskich (1697-1740), Warszawa 1961.

Olszewski H., Epoka saska w ocenie historiografii polskiej, w: Między wielka polityka a szlacheckim partykularzem. Studia z dziejów nowożytnej Polski i Europy, red. K. Wajda, Torun 1993.

Poraziński J., Funkcje polityczne i ustrojowe rad senatu w latach 1697-1717, „Kwartalnik Historyczny" 1984, 51, 1.

Poraziński J., Ordo intermedius? Kilka uwag o politycznej roli senatu w XVII i XVIII wieku, w: Między wielka polityka a szlacheckim partykularzem. Studia z dziejów nowożytnej Polski i Europy, red. K. Wajda, Toruń 1993. 
Prochaska A., Konfederacja tarnogrodzka, „Przewodnik Naukowy i Literacki” 1917, 45, 1-11.

Radwański Z., Prawa kardynalne w Polsce, Poznań 1952, Studia nad historią prawa polskiego, $16,1$.

Stanek W., Generalny zjazd tarnogrodzki w 1715 r., w: Między wielka polityka a szlacheckim partykularzem. Studia z dziejów nowożytnej Polski i Europy, red. K. Wajda, Toruń 1993.

Stanek W., Konfederacje generalne koronne w XVIII wieku, Toruń 1991.

Staszewski J., August II Mocny, Wrocław 1998.

Staszewski J., August II na polskim tronie, w: Polska na przestrzeni wieków, red. J. Tazbir, Warszawa 1995.

Staszewski J., Badania Józefa Andrzeja Gierowskiego nad epoka saska, w: Profesor Józef Andrzej Gierowski jako uczony i nauczyciel, red. M. Markiewicz, Wrocław 2008.

Staszewski J., Czasy saskie - rehabilitacja czy lepsze poznanie?, „Wiadomości Historyczne” 1997, 221, 2.

Staszewski J., Między Wiedniem i Petersburgiem. Uwagi na temat międzynarodowego położenia Rzeczypospolitej w XVII i XVIII w., w: Między Wschodem i Zachodem - Rzeczpospolita XVI-XVIII w. Studia ofiarowane Zbigniewowi Wójcikowi w siedemdziesiąta rocznice urodzin, red. T. Chynczewska-Hennel et al., Warszawa 1993.

Staszewski J., O miejsce w Europie. Stosunki Polski i Saksonii z Francja na przełomie XVII i XVIII w., Warszawa 1973.

Staszewski J., Z listy najczęściej spotykanych błędnych mniemań na temat czasów saskich, „Przegląd Humanistyczny" 1996, 40, 1.

Szujski J., Dzieje Polski, t. 4, Kraków 1866.

Topolski J., Czy istniała w Polsce epoka saska? Czyli metodologiczne implikacje periodyzacji historycznej, w: Między wielka polityka a szlacheckim partykularzem. Studia z dziejów nowożytnej Polski i Europy, red. K. Wajda, Torun 1993.

Topolski J., Polska w czasach nowożytnych. Od środkowoeuropejskiej potęgi do utraty niepodległości (1501-1795), Poznań 1994, Polska. Dzieje narodu, państwa i kultury, t. 2.

Wimmer J., Wojsko Rzeczypospolitej w dobie wojny pótnocnej (1700-1717), Warszawa 1956.

\section{NOTA O AUTORZE}

Arkadiusz Kierys - doktor nauk humanistycznych w zakresie historii, związany z Uniwersytetem Mikołaja Kopernika w Toruniu. Badacz historii historiografii polskiej oraz dziejów opozycji intelektualnej w PRL. Autor monografii: Polska Jasienicy. Biografia publicysty (Kraków 2015) oraz zbioru pism: Historia to nie dziwka. Antologia tekstów Pawła Jasienicy, jego interlokutorów i recenzentów (Kraków 2018). Prezes Stowarzyszenia Rojsty, promującego edukację humanistyczną wśród młodzieży, opracował skrypt do historii dla uczniów szczególnie uzdolnionych humanistycznie: Historia Mundi. Starożytność. Od prehistorii do imperium perskiego (Toruń 2010). Nauczyciel historii w Uniwersyteckim Liceum Ogólnokształcącym w Toruniu. 